\title{
The effects of ageing treatment on bioactive contents and chemical composition of liquid smoke food flavourings
}

\author{
Xing Xin ${ }^{1} \cdot$ Wenyu Zhao ${ }^{1} \cdot$ Sinemobong Essien ${ }^{1} \cdot$ Kiri Dell $^{2} \cdot$ Saeid Baroutian ${ }^{1}$
}

Received: 2 December 2021 / Revised: 16 January 2022 / Accepted: 22 January 2022 / Published online: 4 February 2022

(c) The Author(s) 2022

\begin{abstract}
Liquid smoke food flavouring is an alternative to traditional food smoking. Ageing treatment of liquid smoke can remove tar to improve a consistent sensory experience but traditionally takes months by storage. This study proposed a thermal treatment approach to accelerate the ageing process. Liquid smoke samples from kānuka and hickory woodchips were prepared by fast pyrolysis. The obtained liquid smoke samples were subjected to ageing by storing them at ambient temperature for 18 months. Accelerated ageing of liquid smoke was carried out by heat treatment at $80{ }^{\circ} \mathrm{C}$ for 24 and $48 \mathrm{~h}$. Tar formed during the ageing process, with a yield ranging from 2.2 to $4.1 \mathrm{wt} . \%$. Both ageing treatments resulted in decreases in bioactive content and their activities in terms of total phenolic content (TPC), total flavonoid content (TFC), ferric reducing antioxidant power assay (FRAP) and 2,2-diphenyl-1-picrylhydrazyl scavenging activity (DPPH). Chemical composition and principal component analyses indicated that liquid smoke chemical compositions were influenced by wood type and ageing conditions. It was found that thermal treatment at $80{ }^{\circ} \mathrm{C}$ for $24 \mathrm{~h}$ was sufficient to age liquid smoke.
\end{abstract}

Keywords Liquid smoke $\cdot$ Flavouring $\cdot$ Ageing $\cdot$ Stability $\cdot$ Principal component analysis

\section{Introduction}

Liquid smoke is a food flavouring ingredient derived from woody biomass [1]. Liquid smoking food is fast, safe, and environmental-friendly compared to traditional food smoking [2]. Because the concentrations of polyaromatic hydrocarbons, which are dominantly responsible for the toxicity of smoke flavourings [3], can be eliminated or reduced to below the regulation limits before the use. Liquid smoke can be produced by smouldering, carbonisation, or fast pyrolysis processes [4]. It is commonly applied in food industry as a flavouring additive and preservative for meat, cheeses and seafood [5]. Liquid smoke contains many functional compounds such as phenolics, flavonoids, acids, furans, and ketones giving the treated food a unique and pleasant woody and smoky flavour and aroma [6]. A market study revealed

Saeid Baroutian

s.baroutian@auckland.ac.nz

1 Department of Chemical and Materials Engineering, The University of Auckland, Auckland 1010, New Zealand

2 Faculty of Business and Economics, The University of Auckland, Auckland 1010, New Zealand the global market size of liquid smoke was growing rapidly and had reached 56.5 million USD in 2018 [7].

Some compounds are still chemically active after liquid smoke production, forming tar over a period through factors such as temperature and light $[8,9]$. Tar forming in liquid smoke leads to phase separation, which is unpleasant to consumers [10]. Hence, liquid smoke is usually stored in a tank for a period after production and is referred to as ageing or stationing. Ageing allows liquid smoke to settle and form a tar phase. After removing tar, the resultant liquid smoke is a clear liquid product that is "Generally Recognised as Safe" by the United States Food and Drug Administration [2].

Although ageing is an important process in the liquid smoke production, only a few studies in the public domain have investigated the impact of ageing on liquid smoke properties. An early study investigated the chemical changes of liquid smoke during ageing for 4 months at ambient temperature [11]. Chemical analyses (GC-MS and FTIR) indicated a migration of aromatic hydrocarbons from liquid smoke to the formed tar. Another report used bamboo, oak and pine wood to prepare liquid smoke and aged for 35 months at room temperature [12]. Pyrolysis-Gas Chromatography-Mass Spectrometry (Py-GC-MS) analysis revealed 
the contents of phenolic components decreased with ageing time, and primarily was responsible for tar forming.

Liquid smoke ageing is a simple process of storing in a tank; however, it largely prolongs production time by months [5]. Commercial demands may require a fast production turn around requiring a shortened ageing time. Accelerated ageing of pyrolysis oil has been achieved in hours by a heating treatment at a temperature below $100{ }^{\circ} \mathrm{C}[8,13]$. Pyrolysis oil is a similar product to liquid smoke by pyrolysis of woody biomass [14]. Therefore, accelerated ageing could be applicable to achieve a reduction of hours for liquid smoke ageing.

This study used a fast pyrolysis method to prepare liquid smoke and investigated the effects of storage and accelerated ageing on the bioactive contents. It was hypothesised that bioactive contents would be decreased by ageing treatment due to the decrease of phenolics which primarily contributed to bioactivity [15]. In addition, the changes of chemical composition were analysed by gas chromatography-mass spectrometry (GC-MS) and interpreted by principal component analysis (PCA). This research serves as a practical reference to benefit liquid smoke manufacturing and food research communities.

\section{Materials and methods}

\section{Materials}

Two types of woody biomass were used in this study. Kānuka woodchips were obtained from East Cape of New Zealand. Kānuka (Kunzea ericoides) is a native tea tree species and is commonly used for food smoking in New Zealand [16]. Hickory (Carya tomentosa) woodchips, as a popular smoke source, were purchased from Smokai Limited, New
Zealand. Both woodchips had particle sizes with a range of 2-4 mm to meet the requirements of a fast pyrolysis process. The moisture of woodchips was in the range of 7-10 wt.\% as they were stored in ambient conditions.

Chemicals and reference standards were purchased from Sigma-Aldrich, New Zealand, including gallic acid (purity, 97.5-102.5\%), catechin hydrate (purity $\geq 96 \%$ ), Folin-Ciocalteu's phenol reagent, 1, 1-diphenyl-2-picrylhydrazyl (DPPH) (purity $\geq 95 \%$ ), 6-hydroxy-2,-5,-7,-8-tetramethylchroman-2-carboxylic acid (Trolox) (purity $\geq 98 \%$ ), aluminium chloride (purity $\geq 99 \%$ ), sodium carbonate (purity $\geq 99.9 \%$ ), sodium nitrite (purity $\geq 99 \%$ ) and dichloromethane (DCM) (purity $\geq 99 \%$ ).

\section{Liquid smoke preparation and ageing}

Liquid smoke samples from kānuka and hickory woodchips were produced using a bubbling fluidised-bed fast pyrolysis reactor $(1 \mathrm{~kg} / \mathrm{h})$, as shown in Fig. 1 [17]. The details and procedure of this fast pyrolysis method were provided in the Supplementary data [17, 18]. Briefly, kānuka or hickory woodchips were rapidly decomposed at a temperature of $450{ }^{\circ} \mathrm{C}$ and under a nitrogen atmosphere in the fluidisedbed reactor. Raw liquid smoke was collected by condensation after fast pyrolysis. It was centrifuged at $1000 \mathrm{rpm}$ for $10 \mathrm{~min}$ to separate a thin oil phase and a liquid smoke phase. Fresh liquid smokes produced from kānuka wood were labelled as K-F, and the fresh samples from hickory wood were labelled as H-F as shown in Table 1.

Long-time storage ageing was performed by storing fresh samples in airtight glass bottles $(250 \mathrm{~mL})$ with plastic caps at ambient temperature for 18 months. The bottles were storage in a covered container to avoid exposure to sunlight. Storage ageing is a common approach to improve the sensory properties of liquid smoke due to the changes in

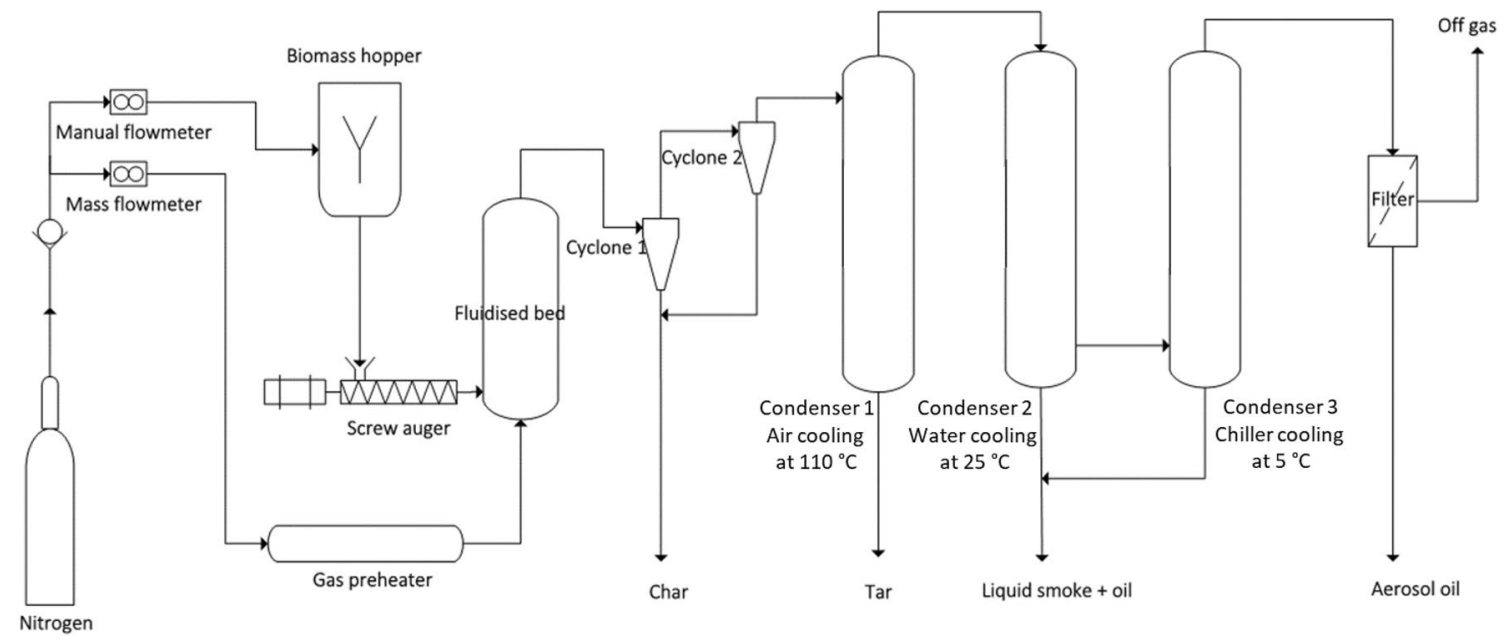

Fig. 1 A laboratory-scale fluidised-bed reactor for liquid smoke production [16] 
Table 1 Liquid smoke samples labelling and description

\begin{tabular}{llll}
\hline Label & Wood type & Ageing method & Ageing time \\
\hline K-Fresh & Kanuka & Freshly produced & Non \\
K-SA & Kanuka & Ambient storage & 18 months \\
K-AA1 & Kanuka & Accelerated ageing at $80^{\circ} \mathrm{C}$ & $24 \mathrm{~h}$ \\
K-AA2 & Kanuka & Accelerated ageing at $80^{\circ} \mathrm{C}$ & $48 \mathrm{~h}$ \\
H-Fresh & Hickory & Freshly produced & Non \\
H-SA & Hickory & Ambient storage & 18 months \\
H-AA1 & Hickory & Accelerated ageing at $80^{\circ} \mathrm{C}$ & $24 \mathrm{~h}$ \\
H-AA2 & Hickory & Accelerated ageing at $80^{\circ} \mathrm{C}$ & $48 \mathrm{~h}$ \\
\hline
\end{tabular}

flavour and chemical composition [11, 15]. These samples were labelled as K-SA and H-SA in Table 1.

Accelerated ageing of liquid smoke was conducted by following a previous study of pyrolysis oil ageing [19]. Firstly, clean airtight glass tubes $(50 \mathrm{~mL})$ with plastic caps were dried at $80{ }^{\circ} \mathrm{C}$ in a conventional oven overnight to remove any moisture. The tubes were weighed before and after transferring $45 \mathrm{~mL}$ of each sample to them. The tubes were placed in an oven at $80{ }^{\circ} \mathrm{C}$ and were sealed after $10 \mathrm{~min}$. For each sample, $24 \mathrm{~h}$ and $48 \mathrm{~h}$ of treatments were applied. Afterwards, the samples were cooled to room temperature and stored at $4{ }^{\circ} \mathrm{C}$ before chemical analysis. Kānuka liquid smoke sample subjected to $24 \mathrm{~h}$ accelerated ageing was labelled as K-AA1, and the $48 \mathrm{~h}$ aged sample was labelled as K-AA2 in Table 1. Likewise, the hickory samples subjected to accelerated ageing at $24 \mathrm{~h}$ and $48 \mathrm{~h}$ were labelled as H-AA1 and H-AA2, respectively.

\section{Determination of bioactive contents}

All liquid smoke samples were analysed for total phenolic content (TPC), total flavonoid content (TFC), ferric reducing antioxidant power assay (FRAP) and 2,2-diphenyl-1-picrylhydrazyl scavenging activity (DPPH). Firstly, liquid smoke samples were diluted in distilled water to a concentration of $10 \mathrm{mg} / \mathrm{mL}$. Folin-Ciocalteu assay was used to determine TPC values with gallic acid standards [20]. An aluminium chloride method was used to determine TFC values with quercetin standards [21]. FRAP assays were conducted with trolox standards [22]. DPPH scavenging capacity was determined with trolox standards [21].

The 96 well plates were incubated in the dark for $60 \mathrm{~min}$ at room temperature before the measurement with an ultraviolet-visible (UV) microplate reader (EnSpire 2300, PerkinElmer). The absorbance values were measured at $765 \mathrm{~nm}$ for TPC, $510 \mathrm{~nm}$ for TFC, $593 \mathrm{~nm}$ for FRAP and $517 \mathrm{~nm}$ for DPPH. Bioactive capacities were expressed as milligram of standard equivalent per gram of liquid smoke: TPC $-\mathrm{mg}$ $\mathrm{GAE} / \mathrm{g}$, TFC $-\mathrm{mg}$ QE/g, FRAP—mg TE/g and DPPH—mg
TE/g. The detailed procedures of these analysis methods were provided in the Supplementary data.

\section{Composition analysis}

Gas Chromatography-Mass Spectrometry (GC-MS) analysis of liquid smoke samples was conducted to identify volatile compounds following a previous study with minor modification [23]. Liquid smoke samples were diluted in distilled water to a concentration of $250 \mathrm{mg} / \mathrm{mL}$. The solutions were then mixed with dichloromethane at a volume ratio of 1:2 (solution: dichloromethane), and the mixtures were agitated at $200 \mathrm{rpm}$ for $6 \mathrm{~h}$. The dichloromethane extracts were filtered by $0.2 \mu \mathrm{m}$ syringe filters before the analysis.

The GC-MS instrument (Shimadzu QP-5000) was equipped with a DB-5HT column. Dichloromethane extract $(1 \mu \mathrm{L})$ was injected at an injection temperature of $280^{\circ} \mathrm{C}$. The oven temperature was increased from 50 to $250{ }^{\circ} \mathrm{C}$ using a $20^{\circ} \mathrm{C} / \mathrm{min}$ heating rate, and was held at $250{ }^{\circ} \mathrm{C}$ for $5 \mathrm{~min}$. Helium gas was used as the carrier with a flow rate of $3 \mathrm{~mL} / \mathrm{min}$. Mass spectra were operated in electron ionisation mode at $70 \mathrm{eV}$, and the mass range was $50-300 \mathrm{amu}$ for acquisition. Volatile compounds were identified by comparing the mass spectra with those in the library NIST and by comparing the data results with previous studies $[18,24$, 25]. Their relative abundances were expressed as the peak area percentages of total ionisation chromatogram (TIC). These results were semi-quantitative since calibrating ion abundances to concentration was not practical considering many identified compounds (Table 2). Instead, peak area percentages of these compounds were used to illustrate the general trends of each compound but not to indicate their actual concentrations.

\section{Principal component analysis}

GC-MS results in this study were further analysed using principal component analysis (PCA) to classify liquid smoke samples. Principal component analysis can reduce the experimental data dimension by transforming a large set of interrelated variables into principal components. It makes the interpretation of complex data straightforward, such as the changes of liquid smoke chemical composition by various factors. Fresh liquid smokes and the aged samples with different conditions were set as the observations. The peak area percentages of the compounds detected by GC-MS were set as the variations. The effects of ageing conditions on the chemical composition were examined. A MATLAB toolbox with MATLAB R2020a software was used to conduct PCA [26]. The toolbox gave visualising results including plots of scores and loadings. 
Table 2 Identified volatile compounds by GC-MS analysis with the average percentages of relative peak area (Standard deviations of the average percentages are presented in Table S1 in Supplementary data)

\begin{tabular}{|c|c|c|c|c|c|c|c|c|c|}
\hline Compound name & Chemical group & $\mathrm{K}-\mathrm{F}$ & $\mathrm{K}-\mathrm{SA}$ & K-AA1 & K-AA2 & $\mathrm{H}-\mathrm{F}$ & $\mathrm{H}-\mathrm{SA}$ & H-AA1 & H-AA2 \\
\hline 1-Phenylcyclohexanecarboxylic acid & Acids1 & 1.4 & 2.1 & 2.3 & 2.3 & 1.4 & 2.0 & 1.9 & 1.8 \\
\hline Pentadecanoic acid & Acids2 & 0.5 & 1.4 & 2.0 & 2.0 & 0.5 & 1.9 & 2.1 & 2.2 \\
\hline Octadecanoic acid & Acids3 & 0.3 & 0.8 & 1.2 & 1.3 & 0.2 & 1.0 & 0.8 & 1.3 \\
\hline Butanal & Carbonyls1 & 1.7 & 1.7 & 1.8 & 1.8 & 1.9 & 1.7 & 1.9 & 1.9 \\
\hline 4-Methyl-5H-furan-2-one & Carbonyls10 & 1.3 & 1.2 & 1.7 & 1.7 & 1.4 & 1.1 & 1.6 & 1.6 \\
\hline 3-Tert-butylfuran-2,5-dione & Carbonyls11 & 0.7 & 0.9 & 0.9 & 0.8 & 0.8 & 0.9 & 1.0 & 0.9 \\
\hline 2-cyclopenten-1-one, 3-ethyl-2-hydroxy- & Carbonyls12 & 1.1 & 1.3 & 1.1 & 1.1 & 1.0 & 1.5 & 1.3 & 1.3 \\
\hline 2-Methyl-2-cyclopenten-1-one & Carbonyls2 & 2.3 & 2.4 & 2.2 & 2.1 & 2.9 & 2.7 & 2.6 & 2.7 \\
\hline $2(5 \mathrm{H})$-Furanone & Carbonyls3 & 5.7 & 6.7 & 6.1 & 6.0 & 6.1 & 5.4 & 6.1 & 6.0 \\
\hline 5-Methyl-2(5H)-furanone & Carbonyls4 & 1.1 & 1.2 & 1.3 & 1.4 & 1.1 & 1.0 & 1.2 & 1.3 \\
\hline 3-Methyl-2-cyclopenten-1-one & Carbonyls5 & 2.9 & 1.9 & 2.5 & 2.1 & 3.2 & 2.9 & 3.2 & 3.0 \\
\hline 2(5H)-Furanone, 3-methyl- & Carbonyls6 & 1.1 & 1.1 & 1.3 & 1.4 & 1.1 & 1.0 & 1.2 & 1.3 \\
\hline 2-Furanone, 2,5-dihydro-3,5-dimethyl- & Carbonyls7 & 0.9 & 0.6 & 1.5 & 1.5 & 0.8 & 1.3 & 1.3 & 1.4 \\
\hline 1,2-Cyclopentanedione, 3-methyl- & Carbonyls8 & 5.8 & 7.0 & 5.9 & 6.5 & 6.8 & 7.7 & 7.2 & 7.6 \\
\hline 2-cyclopenten-1-one 2 3-dimethyl- & Carbonyls9 & 0.8 & 0.7 & 0.8 & 0.8 & 1.2 & 1.1 & 1.0 & 1.1 \\
\hline butanoic acid, 3-hydroxy-, methyl & Esters1 & 0.9 & 1.8 & 1.6 & 2.5 & 1.1 & 1.4 & 1.2 & 1.8 \\
\hline Sulphurous acid, isobutyl 2-methyl- & Esters2 & 1.0 & 1.2 & 1.0 & 0.9 & 1.3 & 1.3 & 1.2 & 0.9 \\
\hline 2-Hydroxyisocaproic acid, methyl ether, methyl ester & Esters3 & 0.7 & 0.9 & 0.7 & 0.7 & 1.0 & 1.0 & 0.9 & 0.8 \\
\hline 2,5-Dimethoxytetrahydrofuran & Esters4 & 1.3 & 1.8 & 1.6 & 1.6 & 1.4 & 1.4 & 1.4 & 1.3 \\
\hline 1,2-Ethanediol, 1,2-di-2-furanyl- & Furans1 & 1.0 & 0.9 & 1.2 & 1.2 & 0.8 & 1.5 & 1.2 & 1.0 \\
\hline Acetylfuran & Furans2 & 0.9 & 1.2 & 1.2 & 1.3 & 1.1 & 1.2 & 1.2 & 1.3 \\
\hline 3,5-Dimethoxy-4-hydroxyphenylacetic acid & Phenols1 & 1.8 & 1.8 & 0.9 & 1.5 & 1.3 & 1.9 & 0.8 & 1.0 \\
\hline Phenol, 2,3-dimethyl- & Phenols10 & 0.6 & 0.5 & 0.6 & 0.9 & 0.7 & 0.7 & 0.8 & 1.1 \\
\hline 2,3-Dihydroxybenzaldehyde & Phenols11 & 0.7 & 0.8 & 1.1 & 0.6 & 0.9 & 0.9 & 0.9 & 0.9 \\
\hline Creosol & Phenols 12 & 6.8 & 5.8 & 4.5 & 3.9 & 5.0 & 3.7 & 3.9 & 3.4 \\
\hline Catechol & Phenols13 & 4.0 & 4.5 & 4.8 & 5.0 & 3.5 & 4.2 & 4.4 & 4.4 \\
\hline 1,3-Benzenediol, 2-methyl- & Phenols14 & 3.3 & 1.2 & 1.2 & 1.2 & 3.7 & 2.0 & 1.8 & 1.6 \\
\hline Phenol, 4-ethyl-2-methoxy- & Phenols 15 & 3.9 & 4.9 & 3.5 & 3.5 & 3.5 & 4.1 & 3.6 & 3.6 \\
\hline Phenol, 2,6-dimethoxy- & Phenols16 & 7.9 & 7.3 & 7.1 & 7.1 & 9.0 & 9.0 & 8.7 & 8.5 \\
\hline Phenol, 2-methoxy(2-propenyl)- & Phenols17 & 1.3 & 1.4 & 0.9 & 0.9 & 1.2 & 1.1 & 1.0 & 0.9 \\
\hline 4-Ethylthiophenol & Phenols 18 & 1.2 & 0.7 & 1.0 & 1.0 & 1.2 & 1.1 & 1.0 & 1.0 \\
\hline Vanillin & Phenols19 & 2.1 & 2.3 & 3.0 & 2.9 & 2.0 & 1.6 & 2.3 & 2.1 \\
\hline 3,5-Dimethoxy-4-hydroxycinnamic acid & Phenols2 & 1.5 & 1.0 & 1.0 & 1.1 & 1.3 & 1.5 & 0.9 & 0.8 \\
\hline trans-Isoeugenol & Phenols20 & 1.0 & 1.3 & 1.1 & 0.9 & 0.9 & 1.2 & 0.8 & 0.9 \\
\hline 3,5-Dimethoxy-4-hydroxytoluene & Phenols21 & 3.2 & 0.8 & 0.8 & 0.7 & 4.3 & 2.6 & 2.3 & 2.2 \\
\hline Apocynin & Phenols22 & 1.7 & 1.8 & 1.8 & 1.8 & 1.5 & 1.2 & 1.5 & 1.7 \\
\hline 2,4-Di-tert-butylphenol & Phenols23 & 0.7 & 1.5 & 1.7 & 1.4 & 0.6 & 1.2 & 1.5 & 1.3 \\
\hline 3,4,5-Trimethoxytoluene & Phenols24 & 1.2 & 0.6 & 0.6 & 0.3 & 1.4 & 1.6 & 1.1 & 1.0 \\
\hline 3,5-Dimethyl-4-hydroxybenzaldehyde & Phenols25 & 2.4 & 1.7 & 3.0 & 3.0 & 2.4 & 1.8 & 2.6 & 2.5 \\
\hline 4-Acetyl-2,6-dimethoxyphenyl acetate & Phenols26 & 2.3 & 2.0 & 2.5 & 2.6 & 2.2 & 2.1 & 2.3 & 2.2 \\
\hline Benzenepropanol, 4-hydroxy-3-methoxy- & Phenols3 & 1.6 & 1.4 & 1.5 & 1.5 & 1.1 & 1.1 & 0.8 & 0.9 \\
\hline Sinapyl alcohol & Phenols4 & 0.8 & 1.4 & 1.6 & 1.5 & 0.6 & 0.7 & 0.7 & 0.8 \\
\hline Phenol & Phenols5 & 1.4 & 0.7 & 1.4 & 1.3 & 2.1 & 1.3 & 2.1 & 2.1 \\
\hline Phenol, 3-methyl- & Phenols6 & 2.0 & 1.9 & 2.1 & 2.0 & 2.2 & 2.3 & 2.3 & 2.3 \\
\hline Phenol, 3-methyl- & Phenols7 & 1.9 & 1.0 & 1.7 & 1.6 & 2.5 & 1.8 & 2.4 & 2.3 \\
\hline Phenol, 2-methoxy- & Phenols8 & 11.7 & 10.7 & 9.9 & 9.6 & 7.4 & 7.4 & 7.0 & 6.9 \\
\hline Maltol & Phenols9 & 0.7 & 1.0 & 0.8 & 0.9 & 0.5 & 0.8 & 0.8 & 0.9 \\
\hline
\end{tabular}




\section{Statistical analysis}

All the analyses in this study were conducted in triplicate, and the results were presented as mean values \pm standard deviation $(n=3)$. Analysis of variance was performed using SPSS 9.05 (Chicago, USA). The difference between means was analysed using Duncan's test, and statistical significance was considered at $p<0.05$.

\section{Results and discussion}

\section{Liquid smoke ageing treatments}

Figure 2 shows the yields of kānuka and hickory liquid smokes after separating tar in storage and accelerated treatments. These ageing treatments all caused tar forming and led to mass loss of liquid smoke to different extents. It was observed that the changes in the yield of kānuka and hickory liquid smokes had the same trend under these ageing treatments. The highest yield (97.8 wt.\%) was obtained when the kānuka and hickory liquid smokes subjected to 18 months storage at ambient temperature (K-SA and H-SA). The kānuka and hickory liquid smokes thermally treated at $80^{\circ} \mathrm{C}$ for $24 \mathrm{~h}$ had the second highest yield of 97.4 and 97.0 $\mathrm{wt} \%$, respectively. Thermal treatment at $80^{\circ} \mathrm{C}$ for $48 \mathrm{~h}$ led to further yield decreases to $96.5 \mathrm{wt}$ \% for kānuka liquid smoke and $95.9 \mathrm{wt} . \%$ for hickory liquid smoke. The high yields of liquid smoke indicated the mass loss in ageing treatments was minor.

The reduction of liquid smoke yield indicated the increase of tar forming over the ageing period. The results in Fig. 2

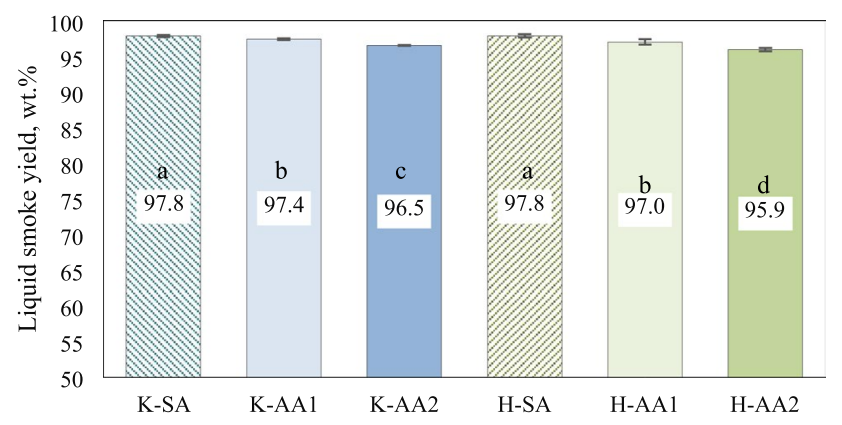

Fig. 2 Liquid smoke yields after different ageing treatments. Error bars correspond to standard deviations of the mean $(n=3)$. The columns with the same letters indicate no significance at $p<0.05$. K-Fresh (freshly produced liquid smoke from Kanuka wood); K-SA (Kanuka liquid smoke ambient stored for 18 months); K-AA1 (Kanuka liquid smoke accelerated aged for $24 \mathrm{~h}$ ); K-AA2 (Kanuka liquid smoke accelerated aged for $48 \mathrm{~h}$ ); H-Fresh (freshly produced liquid smoke from Hickory wood); H-SA (Hickory liquid smoke ambient stored for 18 months); H-AA1 (Hickory liquid smoke accelerated aged for $24 \mathrm{~h}$ ); H-AA2 (Hickory liquid smoke accelerated aged for $48 \mathrm{~h}$ ) revealed accelerated ageing was a severer ageing treatment than storage ageing because of more formed tar. A previous study on accelerated ageing of pyrolysis oil reported that an increase of thermal treatment temperature or time could cause the growth of tar formation due to the polymerisation of phenolics with aldehydes [13]. It was also reported that the stability of thermally treated samples could be essentially improved because active compounds are transformed to tar [27]. It was also noted in Fig. 2 that tar formtion was minor (2.2-4.1 wt.\%) in all ageing treatments, although statistical significance was found among them. Presumably, it may cause changes of bioactive contents due to the loss of phenolics to different extents in tar forming.

\section{Effects on bioactive contents and activities}

Figure 3 shows TPC values for fresh and aged liquid smoke samples. TPC is an important indicator of the antioxidant capacity, antimicrobial ability, and flavouring intensity of liquid smoke [28]. In addition, phenolic compounds are the most abundant functional groups in liquid smoke. Regarding kānuka liquid smokes, fresh sample presented the highest value of $54.3 \mathrm{mg} \mathrm{GAE} / \mathrm{g}$. Storage ageing decreased the TPC value to $49.1 \mathrm{mg}$ GAE/g, and accelerated ageing further reduced it to $44.2 \mathrm{mg} \mathrm{GAE} / \mathrm{g}$. The decrease in TPC value was also observed in the results of hickory liquid smokes. The TPC of hickory liquid smoke decreased from $62.8 \mathrm{mg}$ $\mathrm{GAE} / \mathrm{g}$ for the fresh sample to $42.5 \mathrm{mg} \mathrm{GAE} / \mathrm{g}$ for thermally treated for $48 \mathrm{~h}$. A previous study by a pyrolysis-gas chromatography-mass spectrometry analysis showed storage ageing for 35 months at ambient temperature led to approximately $50 \%$ decrease of phenolics in liquid smoke [12].

Figure 3 also shows the TFC values of the fresh and aged liquid smoke samples. Flavonoids are another important group of compounds presented in liquid smoke contributing to the antioxidant and antimicrobial activities [29]. The fresh liquid smoke showed the highest values of $60.2 \mathrm{mg}$ $\mathrm{QE} / \mathrm{g}$ for kānuka and $58.2 \mathrm{mg} \mathrm{QE} / \mathrm{g}$ for hickory. The values were decreased after ageing treatments, while storage ageing led to slightly more reduction than accelerated ageing. It implied that flavonoids were relatively stable under thermal treatment than phenolics, because phenolics had more chemically active sidechains, such as hydroxy.

Figure 4 shows the antioxidant capacities of fresh and aged liquid smoke samples in terms of FRAP and DPPH. Ferric reducing power and free radical scavenging activity are significant indicators of the potential antioxidant capacity for liquid smoke [30]. A previous study showed that syringol, catechol and 3-methoxycatechol were the important contributors to the antioxidant capacity [31]. Fresh kānuka and hickory liquid smokes both presented the highest values of FRAP at around $73 \mathrm{mg}$ TE/g. Storage and accelerated ageing treatments all decreased the FRAP value to 
Fig. 3 TPC (a) and TFC (b) values of liquid smoke after ageing treatments. Error bars correspond to standard deviations of the mean $(n=3)$. The columns with the same letters indicate no significance at $p<0.05$. K-Fresh (freshly produced liquid smoke from Kanuka wood); K-SA (Kanuka liquid smoke ambient stored for 18 months); K-AA1 (Kanuka liquid smoke accelerated aged for $24 \mathrm{~h}$ ); K-AA2 (Kanuka liquid smoke accelerated aged for $48 \mathrm{~h}$ ); H-Fresh (freshly produced liquid smoke from Hickory wood); H-SA (Hickory liquid smoke ambient stored for 18 months); H-AA1 (Hickory liquid smoke accelerated aged for $24 \mathrm{~h}$ ); H-AA2 (Hickory liquid smoke accelerated aged for $48 \mathrm{~h}$ )

Fig. 4 FRAP and DPPH values of liquid smoke after ageing treatments. Error bars correspond to standard deviations of the mean $(n=3)$. The columns with the same letters indicate no significance at $p<0.05$. K-Fresh (freshly produced liquid smoke from Kanuka wood); K-SA

(Kanuka liquid smoke ambient stored for 18 months); K-AA1 (Kanuka liquid smoke accelerated aged for $24 \mathrm{~h}$ ); K-AA2 (Kanuka liquid smoke accelerated aged for $48 \mathrm{~h}$ ); H-Fresh (freshly produced liquid smoke from Hickory wood); H-SA (Hickory liquid smoke ambient stored for 18 months); H-AA1 (Hickory liquid smoke accelerated aged for $24 \mathrm{~h}$ ); H-AA2 (Hickory liquid smoke accelerated aged for $48 \mathrm{~h}$ ) (a)
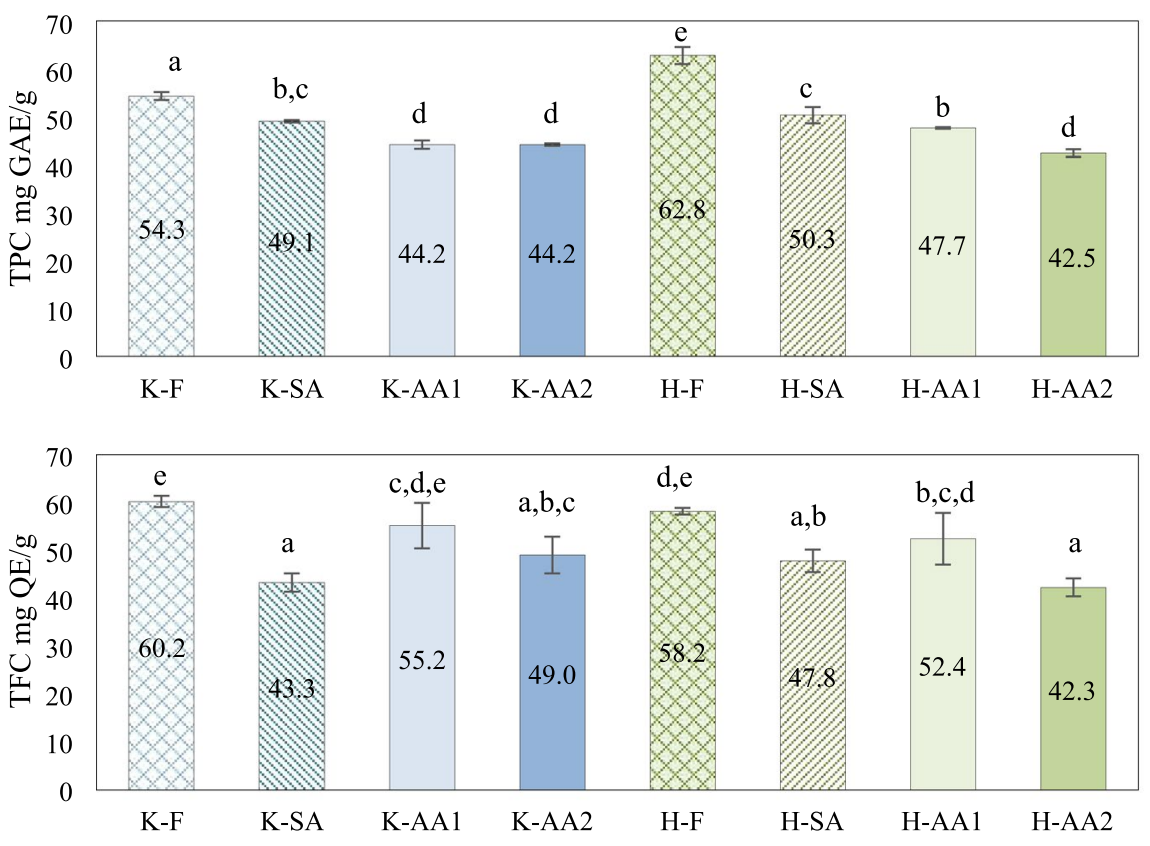

(a)

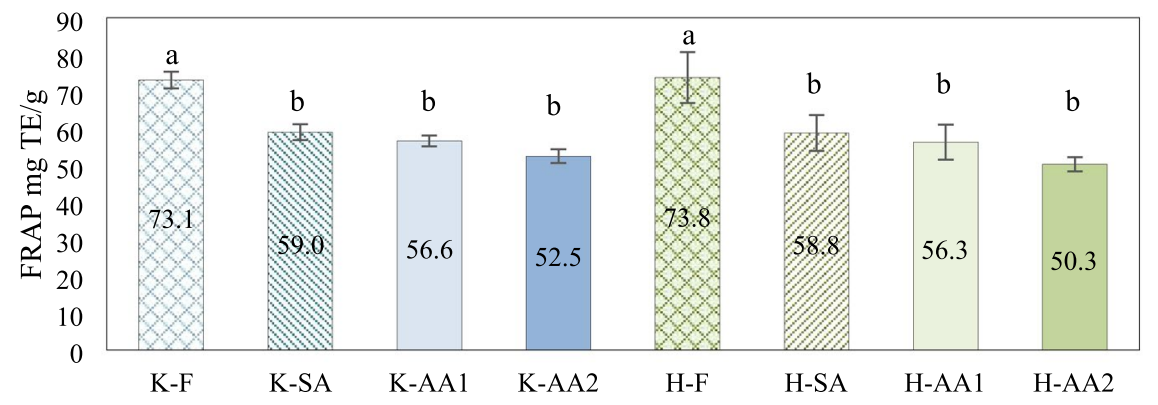

(b)

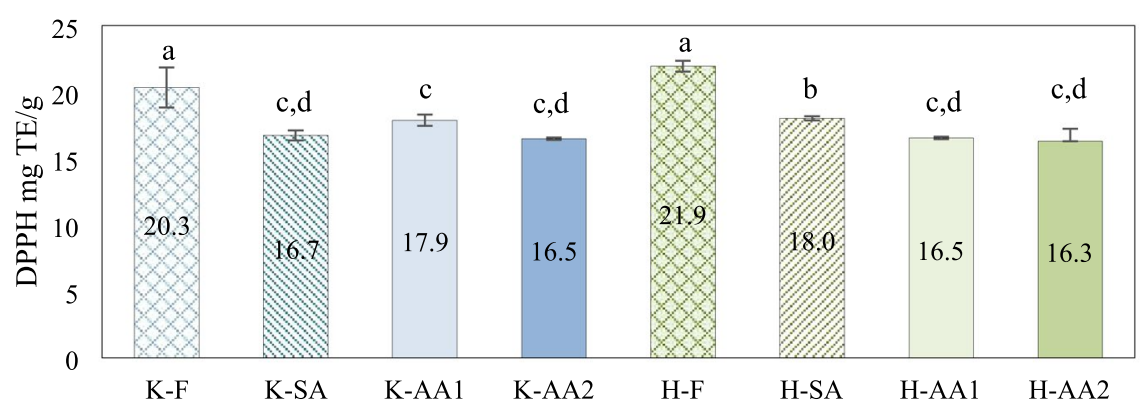

the same extent in the range of 50.3-59.0 $\mathrm{mg} \mathrm{TE} / \mathrm{g}$ with no statistically significant difference. DPPH results confirmed the negative effect of ageing treatment on liquid smoke antioxidant activity.

\section{Effects on chemical composition}

GC-MS results of the fresh and aged liquid smoke samples are presented in Table 2 with the relevant abundance of each identified compound. The standard deviations of the average percentages are presented in Table S1 in Supplementary data. These compounds are grouped into acids, furans, carbonyls, esters and phenols based on their chemical functionality. Phenols were the major compounds, as shown in Table 2. The most abundant phenol in all the samples were Phenols8 (phenol, 2-methoxy-), which is also known as guaiacol, and Phenols 12 (creosol). The comparison of area percentages of Phenols 8 and Phenols 12 indicated storage 
ageing caused the loss and accelerated ageing led to a further reduction. This trend agreed with the results of liquid smoke bioactive content andantioxidant capacity.

Carbonyls and furans are contributors to food colouring and texture changes, and they present synergistic effects on food aroma and flavour along with phenols [32]. As shown in Table 2, the important carbonyls were Carbonyls3 (2(5H)-Furanone), and Carbonyls8 (1,2-cyclopentanedione, 3-methyl-), and the furans shared relatively low peak percentages. It was observed that the percentages of carbonyls and furans were slightly increased after ageing treatments or kept steady, suggesting carbonyls and furans were relatively stable during ageing.

Acids and esters were also identified by GC-MS, as shown in Table 2. Although their peak percentages were low, their presence are essential to enrich liquid smoke sensory profile [32]. The results showed that peak percentages of the long-chain organic acids were increased by ageing treatments, while the percentages of esters were just fluctuated at very low values. It would be worthy to note that light molecular weight acids such as acetic acid were important compounds of liquid smoke [3]. They were not detected in this study because dichloromethane extraction before GC-MS analysis could not recover these polar compounds [33].

\section{Principal component analysis}

Principal component analysis of liquid smoke chemical composition from GC-MS results generated scores plot shown in Fig. 5 and loadings plot in Fig. 6. Principal component 1 (PC1) accounted for $38.61 \%$ of the variation among the ageing treatment, and principal component 2 (PC2) accounted for $26.63 \%$. The scores plot shows how the liquid smoke samples were different to each other by their relative locations [34]. A long distance of the samples from each other means a large variation in their chemical compositions. The loadings plot shows the contributions of the functional compounds (Table 2) to the variation in the liquid smoke samples [34]. A compound located away from the coordinate origin indicates the importance of its contribution to PC1 and PC2 with a positive or negative correlation defined by the scores plot.

The two samples, K-AA1 and K-AA2, were clustered in the scores plot (Fig. 5), likewise samples H-AA1 and H-AA2. It revealed that accelerated ageing treatment for $24 \mathrm{~h}$ had a similar effect on liquid smoke chemical composition as the ageing for $48 \mathrm{~h}$. In other words, a heating time longer than $24 \mathrm{~h}$ did not have a significant influence, which is in agreement with the trends found from the results of bioactive contents and activities in Figs. 2 and 3. The rest of samples were scattered in the plot indicating the differences in their chemical composition. Therefore, wood type

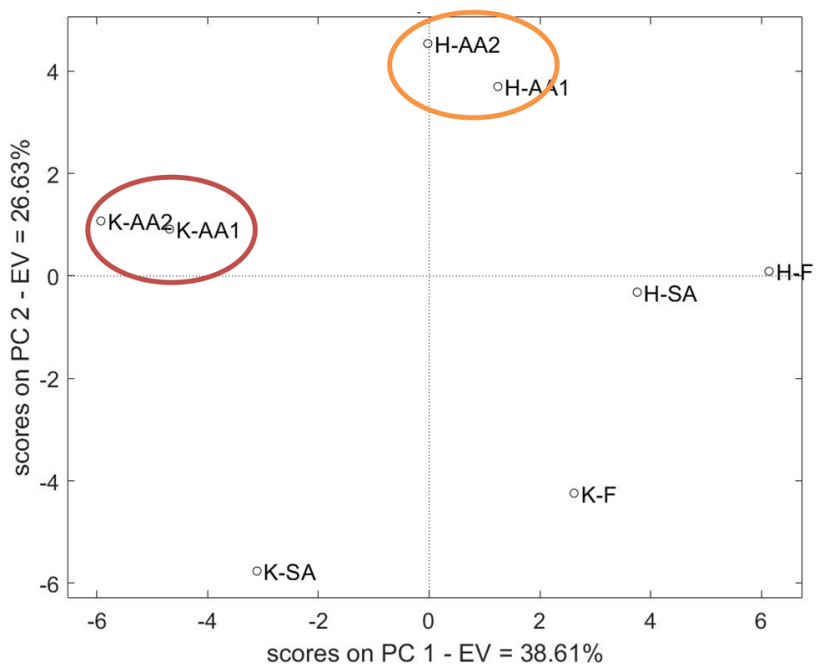

Fig. 5 Scores plot of PC1 and PC2 for principal component analysis of liquid smoke volatile compounds. K-Fresh (freshly produced liquid smoke from Kanuka wood); K-SA (Kanuka liquid smoke ambient stored for 18 months); K-AA1 (Kanuka liquid smoke accelerated aged for $24 \mathrm{~h}$ ); K-AA2 (Kanuka liquid smoke accelerated aged for $48 \mathrm{~h}$ ); H-Fresh (freshly produced liquid smoke from Hickory wood); H-SA (Hickory liquid smoke ambient stored for 18 months); H-AA1 (Hickory liquid smoke accelerated aged for $24 \mathrm{~h}$ ); H-AA2 (Hickory liquid smoke accelerated aged for $48 \mathrm{~h}$ )

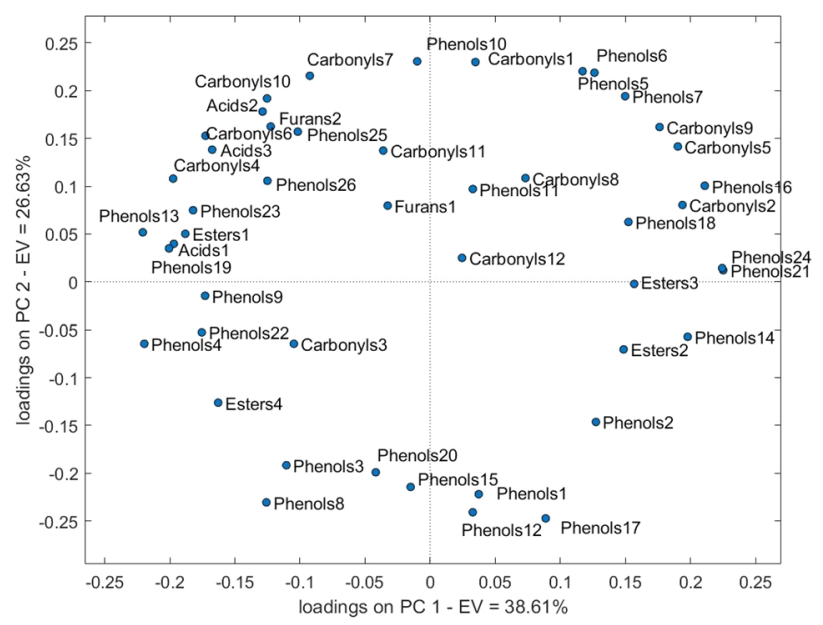

Fig. 6 Loadings plot of PC1 and PC2 for principal component analysis of liquid smoke volatile compounds

and storage ageing were important factors for the resultant liquid smoke.

The loadings plot in Fig. 6 showed PC1 was positively correlated to phenols located on the right side, including Phenols21 (3,5-dimethoxy-4-hydroxytoluene) and Phenols24 (3,4,5-trimethoxytoluene). The decrease of their peak percentages (Table 2) strongly contributed to the shift of liquid smoke samples to the left side on the scores plot (Fig. 5). 
It explains that aged liquid smokes were always located on the left side of fresh samples. Table 2 also suggests that ageing treatment leads to the loss of Phenols21 and Phenols24.

\section{Conclusion}

Ageing of fast pyrolysis liquid smoke was conducted by storage at ambient temperature for 18 months and thermal treatment at $80{ }^{\circ} \mathrm{C}$ for $24 \mathrm{~h}$ or $48 \mathrm{~h}$. This study demonstrated that thermal treatment could be a novel approach to accelerate the liquid smoke ageing process. Storage ageing led to tar forming with a yield of approximately $2.2 \mathrm{wt} . \%$, while thermal treatments slightly increased the tar yield up to 4.1 wt.\%. Bioactive content (TPC and TFC values) of liquid smoke were decreased by all the ageing treatments, while it was found that flavonoids were possibly more stable than phenolics under thermal treatment. Thermal treatment did not cause a further significant decrease of the antioxidant capacities in terms of FRAP and DPPH that storage ageing. GC-MS analysis revealed that the loss of guaiacol and creosol during ageing were primarily responsible for the decreases of liquid smoke bioactive content and activities. PCA revealed thermal treatment for $24 \mathrm{~h}$ was sufficient to age liquid smoke. The liquid smoke chemical composition was strongly influenced by wood type and ageing conditions. Further study should investigate the effects of liquid smoke ageing on the antimicrobial activity and sensory profile.

Supplementary Information The online version contains supplementary material available at https://doi.org/10.1007/s00217-022-03976-2.

Acknowledgements The authors acknowledge the University of Auckland FRDF Grant 3719621.

Funding Open Access funding enabled and organized by CAUL and its Member Institutions.

\section{Declarations}

Conflict of interest The authors declare that they have no known competing financial interests or personal relationships that could have appeared to influence the work reported in this paper.

Compliance with ethics requirements This article does not contain any studies with human or animal subjects.

Open Access This article is licensed under a Creative Commons Attribution 4.0 International License, which permits use, sharing, adaptation, distribution and reproduction in any medium or format, as long as you give appropriate credit to the original author(s) and the source, provide a link to the Creative Commons licence, and indicate if changes were made. The images or other third party material in this article are included in the article's Creative Commons licence, unless indicated otherwise in a credit line to the material. If material is not included in the article's Creative Commons licence and your intended use is not permitted by statutory regulation or exceeds the permitted use, you will need to obtain permission directly from the copyright holder. To view a copy of this licence, visit http://creativecommons.org/licenses/by/4.0/.

\section{References}

1. Surboyo MDC, Arundina I, Rahayu RP et al (2019) Potential of distilled liquid smoke derived from coconut (Cocos nucifera L) shell for traumatic ulcer healing in diabetic rats. Eur J Dent 13:271-279. https://doi.org/10.1055/s-0039-1693527

2. Šimko P (2005) Factors affecting elimination of polycyclic aromatic hydrocarbons from smoked meat foods and liquid smoke flavorings. Mol Nutr Food Res 49:637-647. https://doi.org/10. 1002/mnfr.200400091

3. Montazeri N, Crapo CA, Oliveira ACM et al (2012) Chemical characterization of commercial liquid smoke products. Food Sci Nutr 1:102-115. https://doi.org/10.1002/fsn3.9

4. Xin X, Dell K, Udugama IA et al (2020) Transforming biomass pyrolysis technologies to produce liquid smoke food flavouring. $\mathrm{J}$ Clean Prod. https://doi.org/10.1016/j.jclepro.2020.125368

5. Lingbeck JM, Cordero P, O'Bryan CA et al (2014) Functionality of liquid smoke as an all-natural antimicrobial in food preservation. Meat Sci 97:197-206. https://doi.org/10.1016/j.meatsci. 2014.02.003

6. Gul O, Dervisoglu M, Mortas M et al (2015) Evaluation of polycyclic aromatic hydrocarbons in Circassian cheese by high-performance liquid chromatography with fluorescence detection. J Food Compos Anal 37:82-86. https://doi.org/10.1016/j.jfca.2014. 07.004

7. Grand View Research (2019) Liquid Smoke Market Size, Share \& Trends Analysis Report By Application (Meat Products, Sauces, Dairy Products, Pet Food), By Region, And Segment Forecasts, 2019-2025. https://www.grandviewresearch.com/industry-analy sis/liquid-smoke-market\#: :text=Industry Insights, to remain a favorable factor. Accessed 1 Sep 2020

8. Alsbou E, Helleur B (2014) Accelerated aging of bio-oil from fast pyrolysis of hardwood. Energy Fuels 28:3224-3235. https://doi. org/10.1021/ef500399n

9. Oasmaa A, Fonts I, Pelaez-Samaniego MR et al (2016) Pyrolysis oil multiphase behavior and phase stability: a review. Energy Fuels 30:6179-6200. https://doi.org/10.1021/acs.energyfuels. $6 \mathrm{~b} 01287$

10. Simon R, de la Calle B, Palme S et al (2005) Composition and analysis of liquid smoke flavouring primary products. J Sep Sci 28:871-882. https://doi.org/10.1002/jssc.200500009

11. Guillen MD, Manzanos MJ (1996) Some changes in an aqueous liquid smoke flavouring during storage in polythene receptacles. Zeitschrift für Leb und Forsch 202:24-29

12. Mun SP, Ku CS (2010) Pyrolysis GC-MS analysis of tars formed during the aging of wood and bamboo crude vinegars. J Wood Sci 56:47-52. https://doi.org/10.1007/s10086-009-1054-0

13. Meng J, Moore A, Tilotta D et al (2014) Toward understanding of bio-oil aging: accelerated aging of bio-oil fractions. ACS Sustain Chem Eng 2:2011-2018. https://doi.org/10.1021/sc500223e

14. Balat M (2011) An overview of the properties and applications of biomass pyrolysis oils. Energy Sources Part A Recover Util Environ Eff 33:674-689. https://doi.org/10.1080/15567030903228914

15. Maga JA (2018) Smoke in food processing, 1st edn. CRC Press

16. Essien SO, Baroutian S, Dell K, Young B (2019) Value-added potential of New Zealand mānuka and kānuka products: A review. Ind Crops Prod 130:198-207. https://doi.org/10.1016/j.indcrop. 2018.12.083 
17. Xin X, Ghoreishi K, An G et al (2021) The effect of liquid smoke obtained from fast pyrolysis of a hardwood on physical properties and shelf life of cheddar cheese. Eur Food Res Technol. https:// doi.org/10.1007/s00217-021-03915-7

18. Xin X, Bissett A, Wang $\mathrm{J}$ et al (2021) Production of liquid smoke using fluidised-bed fast pyrolysis and its application to green lipped mussel meat. Food Control 124:107874. https://doi.org/ 10.1016/j.foodcont.2021.107874

19. Elliott DC, Oasmaa A, Meier D et al (2012) Results of the IEA round robin on viscosity and aging of fast pyrolysis bio-oils: longterm tests and repeatability. Energy Fuels 26:7362-7366. https:// doi.org/10.1021/ef301607v

20. Munir MT, Kheirkhah H, Baroutian S et al (2018) Subcritical water extraction of bioactive compounds from waste onion skin. J Clean Prod 183:487-494

21. Essien S, Young B, Baroutian S (2020) Subcritical water extraction for selective recovery of phenolic bioactives from kānuka leaves. J Supercrit Fluids 158:104721

22. Kheirkhah H, Baroutian S, Quek SY (2019) Evaluation of bioactive compounds extracted from Hayward kiwifruit pomace by subcritical water extraction. Food Bioprod Process 115:143-153

23. Guillén MD, Ibargoitia ML (1998) New components with potential antioxidant and organoleptic properties, detected for the first time in liquid smoke flavoring preparations. J Agric Food Chem 46:1276-1285. https://doi.org/10.1021/jf970952x

24. Taruna Syah I, Darmadji P, Pranoto Y (2016) Microencapsulation of refined liquid smoke using maltodextrin produced from broken rice starch. J Food Process Preserv 40:437-446. https://doi.org/ 10.1111/jfpp. 12621

25. Petzold G, Gianelli MP, Bugueño G et al (2014) Encapsulation of liquid smoke flavoring in ca-alginate and ca-alginate-chitosan beads. J Food Sci Technol 51:183-190. https://doi.org/10.1007/ s13197-013-1090-z

26. Ballabio D (2015) A MATLAB toolbox for Principal Component Analysis and unsupervised exploration of data structure. Chemom Intell Lab Syst 149:1-9. https://doi.org/10.1016/j.chemolab.2015. 10.003
27. Hilten RN, Das KC (2010) Comparison of three accelerated aging procedures to assess bio-oil stability. Fuel 89:2741-2749. https:// doi.org/10.1016/j.fuel.2010.03.033

28. Singleton VL, Orthofer R, Lamuela-Raventós RM (1999) [14] Analysis of total phenols and other oxidation substrates and antioxidants by means of folin-ciocalteu reagent. In: Abelson JN, Simon MI (eds) Methods in enzymology, vol 299. Academic Press, pp 152-178. https://doi.org/10.1016/S0076-6879(99) 99017-1

29. Tarawan VM, Mantilidewi KI, Dhini IM et al (2017) Coconut shell liquid smoke promotes burn wound healing. J Evid Based Complementary Altern Med 22:436-440

30. Liu X, Sun H, Gao P et al (2018) Antioxidant properties of compounds isolated from wood vinegar by activity-guided and $\mathrm{pH}-$ gradient extraction. J Wood Chem Technol 38:313-323. https:// doi.org/10.1080/02773813.2018.1488873

31. Loo AY, Jain K, Darah I (2008) Antioxidant activity of compounds isolated from the pyroligneous acid, Rhizophora apiculata. Food Chem 107:1151-1160

32. Maga JA (1987) The flavor chemistry of wood smoke. Food Rev Int 9129:139-183. https://doi.org/10.1080/87559128709540810

33. Guillen MD, Sopelana P, Partearroyo MA (2000) Polycyclic aromatic hydrocarbons in liquid smoke flavorings obtained from different types of wood. Effect of storage in polyethylene flasks on their concentrations. J Agric Food Chem 48:5083-5087. https:// doi.org/10.1021/jf000371z

34. Xin X, Pang S, de Miguel MF, Torr KM (2019) The effect of biomass pretreatment on catalytic pyrolysis products of pine wood by Py-GC/MS and principal component analysis. J Anal Appl Pyrol 138:145-153. https://doi.org/10.1016/j.jaap.2018.12.018

Publisher's Note Springer Nature remains neutral with regard to jurisdictional claims in published maps and institutional affiliations. 